\title{
The formation of Soviet cultural theory of music (1917-1948)
}

\author{
Elina Viljanen ${ }^{1} \mathbb{D}$ \\ Published online: 20 February 2020 \\ (c) The Author(s) 2020
}

\begin{abstract}
This article explores the continuities and discontinuities of pre-Revolutionary intellectual traditions in 1920s Soviet culture and the Stalin-era cultural revolution. Through examination of the pre-revolutionary philosophical legacy underpinning Soviet musicological theory, I demonstrate that there are decisive features, such as Soviet Prometheanism, that characterize the musicology of the 1920s that both underline and differ from the pre-revolutionary philosophy of music and the musicology of the 1930s. I offer the basic outlines of a Soviet cultural theory of music formulated by Russian music critic, historian, composer and musicologist Boris Asafiev (1884-1949) in the 1920s. Explaining and describing what I mean by a particular cultural theory of music in the Soviet context forms the core issue of my article.
\end{abstract}

Keywords Soviet culture - Soviet musicology $\cdot$ Music $\cdot$ Cultural revolution · Cultural theory $\cdot$ Soviet philosophy $\cdot$ Cultural politics $\cdot$ Leninism $\cdot$ Stalinism $\cdot$ Boris Asafiev $\cdot$ Soviet intellectual history

Boris Asafiev (1884-1949) played an indisputably important role in the development of Soviet cultural and educational thought on music. He was one of the intellectuals who, despite the ideological antagonism of Stalin's so-called 'Great Break' (1928-1931), carried on his intellectual work without interruption up until 1948. The most interesting aspect of Boris Asafiev's two-part theory Musical Form as a Process (1930, MFP from now on) and Intonation (1947) is not simply that it was

The article is based on my doctoral thesis, The Problem of the Modern and Tradition: Early Soviet Musical Culture and the Musicological Theory of Boris Asafiev (1884-1949), defended at the University of Helsinki. I thank Rebecca Mitchell and the anonymous reviewers for their comments on an earlier draft of this article.

Elina Viljanen

elina.viljanen@helsinki.fi

1 The Department of Philosophy, History, Culture and Art Studies, Aleksanteri Institute,

University of Helsinki, P.O. Box 42, 00014 Helsinki, Finland 
firmly rooted in Silver Age ${ }^{1}$ philosophy; I present six theses that trace how Asafiev developed Silver Age ideas into a concise cultural theory that was applicable in the Soviet context. Although Intonation was a product of rather complex cultural policies, it nevertheless also fulfilled Asafiev's original intellectual and artistic endeavour of establishing music as a cultural discourse.

Kabalevski played a notable role in the Soviet canonization of Asafiev by editing the collected works (1952-1957), which presents a carefully selected sample of texts. In later decades, Orlova $(1965,1970,1982,1984)$ in particular sought to form a more critical portrait of Asafiev's theory and oversaw various republications of texts ignored during the Stalin era. She also co-re-edited Asafiev's biography (Kriukov 1974) in 1984. As a classic of Russian contemporary musicology, Asafiev is also a respected musicologist in the West, considered a 'proto'-semiotician (Osborne 1986, 220; Tarasti 2002, 54). However, Asafiev's double-dealing with the Soviet government is an issue of critical archival study in post-Soviet historiography (Herrala 2012; Zuk 2019).

Whereas historians often lack an understanding of Asafiev's theory, which indisputably influences the overall interpretation of Asafiev as a historical figure, theoreticians lack the political-historical context that explains his theory. I analyze here some of the results of my study on the previously unexplored and non-contextualized development of Asafiev's theory in the 1920s. My hermeneutical method consists of an endeavour to find a less polarizing and moralizing way to approach an individual who created many of the ideals and theoretical formulations of Stalinist musical aesthetics. Rather than approaching Asafiev's theory from a Stalin-era perspective (Taruskin 2010; Zuk 2019), or alternatively, from the viewpoint of the 'suppressed' project of the avant-garde (Valkova 1999), I ask the following questions: What in fact is so 'Soviet' in Asafiev's musicological thinking? How and why did Asafiev become a Soviet theoretician, and what is the content of his theory from the perspective of tradition? How and why did Asafiev transfer the Russian Silver Age legacy to the Soviet Union, and what was generated through this process? Finally, does this outcome correspond to our current conception of socialist realism as a particular cultural-political, cultural-historical and intellectual-historical concept of music? I would like to think that the answers to the aforementioned questions contribute to the field of Soviet cultural studies by helping to find more logic and reason when explaining the versatile output of an individual who contributed to socialist realist aesthetics and artistic culture.

Asafiev's theoretical ideas were formulated in the context of the New Economic Policy (NEP, ${ }^{2}$ 1921-1928) as a response to the Leninist cultural revolutionary programme. In this context, I find Clark's (1996) concept of Soviet Prometheanism applicable not only because the musical intelligentsia also participated in social construction and the education of the new Soviet citizen, but because prometheanism

\footnotetext{
1 The phase 1890-1917 is generally known as the Silver Age of Russian culture; a name given posthumously to the writers who saw themselves as the continuers and developers of the Russian Golden Age, especially Pushkin (Gasparov et al. eds. 1992).

${ }^{2}$ Novaia ekonomicheskaia politika.
} 
portrays the legacy of the Silver Age culture in Asafiev's thinking. The central idea of Soviet Prometheanism was that science could serve as a vehicle for the kind of transformation sought by the Russian Revolution (Clark 1996, 208). Seen as a broad Promethean discourse, cultural revolution displays the gradual emergence of Soviet culture beyond and prior to the more straightforward language of the politically motivated aesthetic codex of socialist realism under Stalin. In Asafiev's output, the Promethean educative mission is related to the cognition of music. He develops his own concept of critical and cultural 'hearing,' which later comes to dominate intonation theory.

With the concept of the 'cultural theory of music,' I do not just refer to Asafiev's intonation theory. Rather, I refer first of all to a particular theoretical current in Asafiev's musicological writings that aims to form a general concept of music as a cultural discourse. As I shall point out, we witness in early Soviet musicological theory a transition from Russian philosophy to Soviet cultural theory with the contribution of Neo-Kantian philosophy. Second, I refer to a theory that became culturally influential during the Soviet cultural revolution and significantly contributed to Soviet/ Russian cultural thought on music. The meaning of Asafiev's theory of intonation in Russian musicology has been aptly portrayed by Panteeleva $(2015,123)$, who goes as far as to say that this theory 'was one of the main reasons for the profound misunderstanding between Russian and Western scholars in the twentieth century.'

Intertextualizing Asafiev's theory helps to explain why he continues to have relevance in Russia. His writings serve as my prism for understanding early Soviet culture and theory of humanities in general, and the position of music in Russian cultural history in particular. Musicology is an interesting example of the general development of the Soviet humanities, while music's particularity and its remote cultural position in comparison to literature and philosophy offers new insight into early Soviet intellectual culture.

Throughout the article, I show one line of development of Soviet humanities by uncovering Asafiev's active role in cultural revolution and by discussing the cultural and individual factors that explain the content of his theory. The Asafiev case indicates that intellectuals and cultural theories of the 1920s played a crucial role as mediators of tradition and introducers of modern ideas into Soviet society. His output offers various particularities for explaining how and why the idea of music as an autonomous cultural discourse with an active power to change society was institutionalized in the Soviet Union. The first section outlines Asafiev's pre-revolutionary cultural philosophical background. I will then describe, via six theses, what I mean by the Soviet cultural theory of music. My theses do not proceed strictly diachronically, although they summarize Asafiev's theoretical development in different contexts. Rather, the logic follows my overall argumentation in explaining Asafiev's cultural theory. My first and second theses are grounded in the claim that Asafiev was a musical revolutionary — an autonomist - who elevated the cultural position of music in Russian society. As a continuation to this idea, I discuss in the third and fourth theses the new cultural and social meanings that Asafiev's theory produced in the hermeneutic framework of the 1920s by analyzing a process that I call the Sovietization of Russian Silver Age aesthetics. My fifth thesis takes a critical stance on Asafiev as a national and nationalist theoretician by claiming that his Soviet 
nationalism can be seen as a critical continuation of Russian Westernism and Slavophilism. My sixth thesis problematizes his theoretical positioning of Soviet music culture during the period of high-Stalinism by focusing on Intonation. Overall, I try to open up the logic of the way modernity and various traditions interacted in Soviet culture via individual theoretical endeavours. The hermeneutics of the way in which the legacies of the Russian cultural past were gradually interwoven into a coherent whole with the new Soviet present in the multitude of individual theories of the 1920s underline Stalin-era culture, which should be studied more from the perspective of discontinuities and continuities of intellectual traditions rather than from a perspective that considers Stalinism as a culture.

\section{The 'Silver Age' origins of Asafiev's theory}

Asafiev's life and works draw a picture of a conscientious, dedicated, ambitious and opportunistic scholar on the one hand. On the other, the music he most passionately wrote about, and the way he addressed it, suggests a slightly melancholic, romantic and sensitive character, one who took music seriously as his patriotic task. Born into a lower-middle-class family in St. Petersburg, Asafiev received both an artistic and a scientific education at the Conservatory (composition) and Imperial University (history), an education that continued both before and after the 1905 Revolution. He rose to the zenith of St. Petersburg cultural life through the 'backdoor' of the main ideologist of the Russian national school of music, Vladimir Stasov, who in his last years continued to act as a patron to young artistic talents. Seeking his way in the world, and with romantic music dreams, Asafiev sat down to play the piano for Stasov's guests in 1904 (Stasov 1962, 235).

Asafiev did not obtain a notable professional position before the 1917 Russian Revolution, however. Seeking a teaching position as a historian, Asafiev's autobiography recounts that he was treated with indifference because of his poor social background (Asafiev [1941], 1974, 436-437). He ended up working as a music critic, consultant and accompanist for Mariinsky Theatre. This gave him a firm background as an opera and ballet critic.

Asafiev's intellectual historical background, which helps explain his neonationalist vision of music, is far from simple. His worldview stems extensively from the cultural philosophical ideas informing Russian 'romantic' modernism, conceived here as an intellectual period that began in the late $19^{\text {th }}$ century. Most of Asafiev's pre-Revolutionary reviews were a response to the persistent nationalist musical trends of his youth. His socially remote childhood and youthful connection with Stasov's rather conservative circles seem to explain why he took notice of the most modern and progressive social, philosophical and aesthetic trends of his time relatively late. The defining moment for Asafiev's cultural vision of music was not as much the failed Revolution of 1905, which provides the background for many important pre-Revolutionary Russian intellectual theories; rather, his understanding of music's cultural mission began to develop in the patriotic context of the First World War. The diagnosis of arrhythmia (1912), which often paralysed Asafiev, prevented him from participating in the war. Instead, he became a critic 
writing under the pseudonym 'Igor Glebov' for the journal Muzyka, founded by a new music ideologue named Vladimir Derzhanovski, whose ideological guidance led Asafiev to study the new choral works of Aleksandr Kastalsky, a representative of the new national religious musical movement (Novoe napravlenie, New Direction). These early articles were not fully reprinted in Russia before 2006 because of their purportedly religious tone (see Glebov [1915], 1980, [1916], 2006). During the war, Asafiev became aware of Russian spiritualist philosophy and neo-nationalist artistic ideologies. He began to engage with certain major philosophical currents of the early twentieth century with the same eclectic manner and nationalist fervour as many contemporary Russian philosophers. Beyond some references to a religious social utopia, Asafiev appeared primarily to be seeking to establish a particular postStasovian nationalist musical criteria.

Asafiev's analyses of Kastalsky bring forth the late Symbolist and Post-Wagnerian search for a musical hero, one who could save Russian culture amidst the violence of the war. They show a continuation and revaluation of the Scriabin myth. Composer Aleksandr Scriabin had been a topic of Silver Age salons during Asafiev's study years. Scriabin's new searching musical language had been influenced by Liszt's quest for new expressive qualities that would break down traditional tonal thinking, whereas Wagner's writings had brought the general idea of the musician as a social activist to Russia in the second half of the nineteenth century (Bartlett 1995, 2011). The idea of art as world transformation, cultivated by Scriabin's intellectual circle, was essential to Wagner (Taruskin 2010, 206). Searching for a new religious awareness, Russian Symbolist poets were interested in a new type of spirituality and the mythology of good and evil. They envisioned an ideal artist who could lead humanity by revealing the previously hidden levels of consciousness through his artistic works. Surpassing the restricted way of seeing the old world, the new artist could save humanity from moral decay. (Tompakova 1997; Groenberg 1997, 103-127; Leikin 2011.) Although Scriabin was not the only Russian composer to accept from Wagner the 'Orphic mission', he became the most important one. As Mitchell (2016) shows, Nietzsche's Russian reception explains the logic behind Scriabin's envisioned role as a demiurge and an elevated 'Russian Wagner' after the 1905 Revolution. Nietzsche provided the impulse for many Russian cultural theoreticians to philosophize about human life as an active field of the human spirit that might serve to construct a new, 'more humane' culture. Scriabin's death during the First World War called for a revaluation of Russian musical culture and its philosophical basis. Something in the envisioned spiritual renewal through music had gone irreversibly wrong (Mitchell 2016).

Asafiev's early interpretations of music's role as a cultural force and its philosophical spell was based on Schopenhauerian and Nietzschean ideas. For Asafiev, Kastalsky appeared as a new Nietzschean-type 'heroic' composer, rather than as an 'orthodox icon' painter who passively submitted his art to the will of God (Glebov [1916], 2006, 274). Among Asafiev's Nietzschean starting points were the notion that music, which imitated literary expression, had lost its primordial essence. Imitative music was passive. Instead, active creative 'becoming' became the basis of a musical aesthetic criteria by which he profiled himself as a modern critic of the Russian nationalist direction in music. Developing the nineteenth-century Russian 
music critic Hermann Larosh's musical formalism, he became an apologist for Tchaikovsky's pure musical Russianness (simfonizm) and Stravinsky's and Prokofiev's new 'dynamic' directions 'full of life', positioning himself against the followers of impressionism and the institutionalised 'academic' Rimski-Korsakov school at the St. Petersburg Conservatory under Aleksandr Glazunov (Glebov 1917, 3-27; 1918, 50-96). Around the time of the Revolutions of 1917, Asafiev gradually grew to believe that his greatest mission as a critic and musicologist was to make Russian music an intellectual discourse that was equal and comparable to national literature and philosophy. In his quest to discover what genuine Russianness meant in music, Asafiev returned to the relationship between music and literature from a new philosophical perspective.

Asafiev's motivation to go deeper into the philosophical sphere reflects his growing ambition to form a genuinely scientific theory of music. His concept of a new active musical perception, or a 'new listener,' arises in its first phase from Russian pre-revolutionary religious criticism of Kant as well as neo-Kantianism. Russian Bergsonism was one of the reactions against German philosophy in general. Between 1917 and 1922, Asafiev applied the theory of Nikolai Lossky, who was Russia's foremost representative of Bergsonism.

Asafiev emphasises throughout his output that the greatest ideal of music is its vitality. First, he determines its philosophical basis and later he gives it sociological, linguistic and historical explanations. According to Asafiev, music is life-like when it realizes a Bergsonian élan vital (vital impulse), the all-encompassing principle that subsumes the ongoing and unpredictable creation of the new. Whereas for Henri Bergson everything static, even 'static' religious faith (institutionalized spirituality and closed morality), failed to achieve the 'supposedly universal divinity', everything that Asafiev brands as static in nature in music criticism has negative connotations (Bergson [1932], cited in Mullarkey 2009, 30).

Lossky's pan-psychism, reformulations of Bergson's philosophical intuitivism and occasional citations of Hegel when repudiating dualism or striving for unity, emerged onto Asafiev's intellectual horizon at a critical moment, creating a lasting influence on Russian musicological thought. Asafiev's epistemological pondering of music followed Lossky's neo-Leibnizianism as distinct from Bergson. Leibniz's Monad (Lossky's 'substantive agent') gained a new 'interactive' definition in Lossky's rather creative philosophical synthesis, reflected in the distinction between the mere 'sound' as material and 'intonation' as spiritualized or 'worked' material, which is interactive. Herein also lies the anthropocentrism of Asafiev's theory of music, which makes it distinct from that of Bergson. Sound itself does not constitute music before it has been recreated, i.e. filtered through the human consciousness high in the hierarchy of conscious life. In this way, sound becomes 'in-toned' and placed within the system of sound relations (Asafiev [1947], 1977, 543). Adopting also Lossky's religious interpretation of Bergson, Asafiev highlighted in 1917 that God and religion were the ultimate goal of music (RGALI, f. 2658, op. 1, d. 220.). However, he accepted this because, for Lossky, God and his kingdom were creative rather than fixed in certain teleological formulas. In MFP, Asafiev's central idea is that the process of musical formation never stops, and thus, music that absolutely corresponds to certain ideas or an abstract scheme does not exist (Asafiev 
[1930], 1971, 22). Such religiosity shows up also in Asafiev's belief about the unity of the world. His organic view of musical form, which should always be seen as a spontaneous creative phenomenon and as an outcome of only one of many possible creative realizations, derives from Lossky's reasoning of free will and his theory of multiplicity in relation to Absolute and One as the basis of all beings. These views not only take us back to Leibnitz, but also to Hegel and to those of a more modern Russian philosopher, Vladimir Solovyov's concepts of 'all-unity' (vseedinstvo) and his reinterpretation of the Slavophile doctrine of 'multiplicity-in-unity' (sobornost') (Gustafson and Kornblatt 1996, 20). Lossky was mostly inspired by Plotinus's Neo-Platonism, the philosophy of One (Edinoe) as the source of all beings (Losski [1915], 1991, 373-374). According to this worldview, the world is seen to consist of energy that is divine in nature. The creative energy of the divine is inherent in the higher being (Bussanich 1996, 38-66; Leroux 1996, 304). This gives us the background for understanding Asafiev's creative foundation as well as the ethicalmostly from a social perspective_-reflections related to it. Like Lossky, Asafiev saw music (or sound in general) as a complete spiritual expression of one's active and 'sympathetic' (Asafiev uses empathetic) existence in the world, on the one hand, and an act of communication on the other-an aspiration to attain spiritual communion with other beings. The foremost 'organic' thesis of Asafiev's Intonation, in the sense of Lossky's philosophy, is the notion that any musical presentation of sound, 'in order to become an intonation, cannot remain isolated; it is either the result of an already given correlation, or it evokes by its appearance a subsequent sound, for only then does musical motion occur with all its characteristics.' (Asafiev [1947], [Tull trans.] 1977, 544.)

Asafiev seems to have had a professional motivation to remain in the Soviet Union after the Russian Revolution. The Bolshevik Revolution opened up many opportunities for an intellectual who came from an insignificant social background and was willing to cooperate with the new government. Asafiev was appointed as a professor of musicology at the Petrograd Institute for Arts History (formerly the Zubov Institute, currently $\mathrm{RIII}^{3}$ ) in 1918. Thus, his professional status changed rapidly, and his fame had spread already before his main theoretical monographs were published. As a patriot who was dedicated to developing national musical life, Asafiev grew into a member of the new Soviet professional cultural-educational intelligentsia who defended tradition but also modernized it. As I will show next, a great deal of his musicological output in the 1920s consists of filtering the nineteenthand early twentieth-century Russian literary tradition of music and the social ideals of the Russian Silver Age through the new language and methodology of modern philosophical science.

\footnotetext{
${ }^{3}$ Rossiisskii institut istorii iskusstv.
} 


\section{Asafiev as a Soviet cultural theoretician: six theses}

Russian musicology was established in an interdisciplinary university context in 1921. Various questions posed by neo-Kantians became relevant in constituting the Soviet humanistic sciences of culture, art, etc. Special mention should be made of the second phase of Russian neo-Kantianism that flourished among others within the sphere of the State Academy of Artistic Science $\left(\mathrm{GAKhN}^{4}\right)$ and RIII in the 1920s. From an intellectual and cultural-historical standpoint, Asafiev and other Russian formalists can be seen as part of a cultural-scientific turn in art studies that preceded the Tartu-Moscow semiotic school. Meanwhile, Asafiev was a cultural theoretician who left a considerable nationalist theoretical legacy for Russian/Soviet musical culture. The following six theses summarize Asafiev's approach to music as a central cultural activity and the national slant of his writings from the point of view of breaking with, continuing and modernizing musical traditions. The theses describe and ground Asafiev as a cultural theoretician, but they can also be seen as an example of a reciprocal relationship of culture and politics that shaped Soviet cultural policy.

1. Asafiev's early writings already demonstrate his approach as a musical revolutionary. Asafiev very early on applied this revolutionary discourse to music. He advocated a new national direction for classical music based on a new conception of music. As a musical revolutionary, the young Asafiev defended classical music tradition against the most radical revolutionary avant-gardists, who threatened to destroy the tradition. ${ }^{5}$ Meanwhile, Asafiev actively combined various Silver Age social, philosophical and aesthetic ideas with early cultural revolutionary discourse when trying to win over the sympathies of the new political authorities. As the 'revolutionary' designer of a new national music discourse, he deconstructed nineteenth-century musical myths. However, he also created various new myths upon which he based his new nationalist, philosophical aesthetic criteria for Soviet music. Asafiev's early musicological output reflects Silver Age literary culture mostly through his rediscovery of nineteenth-century Russian composers in an order different to that presented by Stasov's circle. He distanced himself from the ideology of the 'Russian national school of music,' claiming that the so-called Russian school was less independent of Western forms of music than it asserted. Western measurement in general was unsuitable for Russian musical material, and thus, the underlying principles of musical education and scholarship should be completely renewed in his opinion. Asafiev associated young composers like Prokofiev and Miaskovski with the Russian national tradition more philosophically than musically (see Glebov 1917, 1918).

Asafiev's goal was to elevate the value of music as an autonomous voice of human culture and 'liberate' its former subordinate position to literature in

\footnotetext{
${ }^{4}$ Gosudarstvennaia akademiia khudozhestvennykh nauk.

5 Preserving musical cultural heritage, one of Asafiev's most important tasks in the 1920s, continued the emphasis of Count Valeri Zubov's Institute (RIII), where the central focus had been on preserving architectural and art historical heritage (Sepman 2003, 6).
} 
nineteenth-century programmatic music (Glebov [1918], 2003, 57). In Asafiev's Soviet output, Russian composers are categorized according to this thesis. In comparison with the nineteenth-century idea of programmatic music, Asafiev turned the whole relationship of music and poetry upside down in his articles on poetry and music. The musical origins of poetry were grounded as a cultural anthropological argument in Asafiev's cultural philosophical essays on music before his strict musicological articles. In the essays, he elaborates on what is meant by a 'purely' musical portrayal of human thought and on what a 'pure' sound of music signifies (Glebov 1921, 1922a, b). Building on Silver Age writers, Asafiev held up Pushkin as the ultimate spiritual source of Russian cultural creation. However, at the same time he presents Pushkin foremost as a musical poet, granting him the role of Orpheus. The national poet is able to 'sing' through his poems and stands as a source of Russian musical creativity (Glebov 1922a, 15).

The rich associative language and complex metaphysical inquiry in Asafiev's early articles were not just his way of complicating simple ideas. He attempted gradually to 'musicalize' the whole cultural sphere and claimed that culture could be understood through the faculty of hearing - 'just the way the greatest poets of the Russian Golden Age conceived of the world'. Asafiev claimed that all life was based on movement, which we hear as sound or sounding (action). This understanding should form the basis for a new type of programmatic music in which pure music, rather than words, would take the leading role as narrator (ibid.). Later, this not only grounded Asafiev's neo-Kantian thesis that music is a source of information, but also served as a creative principle: it suggests that we recreate the life of nature in human life from the point of view of our inner perceptions (see Glebov 1923b, 157).

2. Asafiev was an autonomist who elevated the cultural position of music. Asafiev's aforementioned opposition to nineteenth-century programmatic music continued the classic formalist tradition per se. However, Asafiev's formalism was nonetheless based on a different goal than that of Russian Formalist ${ }^{6}$ literary scholarship, which sought a more independent position from its previous social tasks. Asafiev, instead, argued for an increased social position for musicians in Russia, where writers had been traditionally conceived as more important cultural authorities (see Stites 2005, 3-4). Also, Asafiev never employed the word formalism or referenced the Formalist literary school, although he not only followed its various analytical trends, but also contributed to its theoretical framework. Whereas Asafiev avoided 'schools' of thought in general, the term formalism was particularly problematic for him from the standpoint of music history. He argued that Eduard Hanslick's ideas of musical form as a self-sufficient, self-contained structure had been more or less misunderstood throughout Europe, and especially by 'Hanslickians' (Glebov 1929, 539). According to Asafiev, the modern (i.e. Bergson-Lossky) organic philosophical view of form as formation made any attempts to juxtapose form and content an

\footnotetext{
${ }^{6}$ Russian Formalism can be defined as a scholarly attitude rather than any exact method or methodology. The name Formalism came from the interest of scholars in focusing their analysis on the formal principles of literature. They argued that each form of art had its own specific and independent methodological questions.
} 
empty effort. In fact, and as acknowledged today, many of Hanslick's concepts were ground-breaking in the history of modern and modernist musicology (see Karnes 2008, 52-53). As pointed out, Larosh preceded Asafiev in promoting an idea that could be described as 'nationalist formalism.' Larosh idealized the authenticity of Russian folk song as the basic material for Russian national music in comparison to 'Volkslied, air national or ballad' together with his search for 'absolute' musicality, in relation to which he talked about symphonism (Larosh [1885], 2003, 51). Asafiev developed classic formalism further. Like Hanslick, Asafiev did not deny that music conveyed feelings or moods, but he argued that the objective properties of music, rather than people's subjective responses to it, constituted the proper concern of musical aesthetics (see Cook 2013, 33). Hanslick's formalism prepared the philosophical groundwork for a century of structuralist analysis of art in general (Karnes 2008, 21). Asafiev and the Russian Formalists appear as a link in this history.

Asafiev's elevation of music in the cultural hierarchy must be seen in the context of the Leninist cultural revolution, within which Asafiev had to theoretically explain why the musical training of the masses (audience) was culturally essential. According to him, music uniquely contributes to the intellectual and social construction of human culture. Therefore, musicians need to be recognized as important cultural workers. In 1923, Asafiev came up with various neo-Kantian arguments about the uniqueness of music as a cultural discourse. Cassirer's Einsteinian idea of the underlying unity of the sciences or of intellectual unity from the standpoint of relativity served Asafiev in his first serious musicological article 'The Value of Music' (1923a). ${ }^{7}$ In it, he sought to form a self-sufficient science of musicology that argued for the uniqueness of music as a cultural discourse. Asafiev stressed that each art form captures the world from its own perspective, and to understand 'this face' of the world one must already know quite well the very material of art and both its human and physical dimensions, how it is created and perceived, and its essence as a physical material (Glebov 1923a, 6). Cassirer's influence on Asafiev shows up at least in three principal features: first, as an endeavour to give a more independent status to the particular object of study (music); second, as a search for the scientific methodology of music that stems from its own 'artistic' essence, goals, meaning and logic; third, and most importantly, its truth-value. Neo-Kantian considerations formed an essential stage in Asafiev's theory of analytical listening. From this basis, French structuralist sociolinguistics shaped his vision further in the second half of the 1920 s.

The sociolinguistic dimension of Asafiev's theory of music was part of his conscious effort to ground his autonomist theoretical position as an anti-'formalist' one after Trotsky's attacks on literary formalism in (1924). Asafiev's MFP was published almost parallel with Valentin Voloshinov's work Marxism and the Philosophy of Language ([1929], 1986), in which he defined a particular Russian Saussurean

\footnotetext{
7 The article was influenced by Cassirer's Substanzbegriff und Funktionsbegriff, Untersuchungen über die Grundfragen der Erkenntniskritik (1910), "Erkenntnis Theorie nebst den Grenzfragen der Logik" (1913) and the Russian translation (1922) of Zur Einsteinschen Relativitätstheorie. Erkenntnistheoretische Betrachtungen (1921).
} 
School of linguistics, referring to those Russian scholars who based their work on Saussure's theoretical ideas, though with a loose Marxist orientation. Although Asafiev focused on 'musical speech' and not 'verbal speech', and though he adopted ideas from Saussure's student Antoine Meillet (1866-1939), we can link him with this school, which in the mid-1920s participated in the larger political project of developing Soviet society.

The autonomist argument appears in the historical narrative of Asafiev's Intonation (1947), as it presents the history of Western classical music as the protracted 'liberation' (osvobozhdenie) of music from its subordinate position to other arts and all musicological doctrines (Asafiev [1947], 1971, 147, 212.). Asafiev viewed music as approaching its primordial essence of sound as a sign of life in general, whereas his principal theoretical concept musical intonation appears as a sign of human cultural life in particular. The origins of this thought can be traced in Lossky's article 'Sound as a particular realm of being' (1917). As with Lossky, music for Asafiev appears as a source of knowledge and a sign of life. For Lossky, music functioned as a way of getting to know 'life' as it was known to another being, thus offering a spiritual communication between two living beings. This idea also formed the cultural semiotic aspect of Asafiev's theory. Both of Asafiev's theoretical monographs demonstrate a systematic aim to write a concise theoretical work about music as an autonomous 'manifestation of thought' in pure sound, as perceived by a listener. I will return to this idea in the sixth thesis.

3. Asafiev was a cultural revolutionary whose intellectual work unconsciously Sovietizes Russian Silver Age aesthetics. Through his role and reputation as a revolutionary music critic, Glebov, Asafiev gained cultural power-an ability to influence cultural values and hierarchies. He used political rhetoric and contacts to impose his musical views and notion of a cultural utopia. Through a complex interplay between aesthetics, politics, scientific postulates and cultural mission, Asafiev engaged in a Sovietization of Russian Silver Age aesthetics. By participating in the early Soviet project of modernizing Russian culture, Asafiev brought the Russian musical tradition under the critical lens of contemporary European scientific theories. Meanwhile he also modernized the mythology of the Russian Silver Age from a practical point of view for the new society. As will be pointed out in my fourth thesis, Asafiev not only tested Silver Age visions, such as the Promethean power of music, by translating them into the language of modern cultural theory, he also assessed their value through the lens of Soviet cultural politics and how well such visions served the practical life of Soviet society.

Finally, the Sovietization process appears also as a linguistic process. Asafiev rewrote the same ideas in different forms to present them in varying contexts. In the 1920s, this was not done to mask his philosophical views from political authorities. Rather, it was part of his conscious desire to find a new cultural theory of music that would answer the most urgent social problems highlighted by the new political authorities. For example: (1) how to unify a society fragmented by civil war? (2) How to carry out general education in a large country? Through answering these questions, Asafiev reformulated many Silver Age philosophical ideals as a unified scientific cultural theory of music producing new cultural and social meanings and tasks for music and musicians. 
4. Asafiev formulated cultural and social meanings for music that are still strongly imprinted in Russian culture. Asafiev assigned two principal social functions to music, both of which were drawn from Russian Silver Age philosophy. Through them, he theoretically constructed his argument about the important social position of music in Soviet Russia.

Firstly, by Orphic social mission I am referring to the Russian Silver Age ideal of music as a unifying force (see Mitchell 2016). Asafiev's intonation theory answered the problem of the disconnectedness of Russian society by highlighting that music could function as a unifying force in society if we learn to consider music as a channel of communication between creator, performer and listener (Asafiev [1947], 1971, 357). Intonation as an all-unifying communicative concept that determines musical form as a process began to develop around 1925when Asafiev and his colleagues pondered how best to apply Leninist principles in music. ${ }^{8}$ The main theoretical idea came from French sociolinguistics. The 'unifying' social aspect of Saussure's theory made it popular among Russian literature scholars, anthropologists, sociologists, philosophers and art scholars. In Cours de linguistique générale, Saussure perceived language as a structured social code. His idea that speech was created from the words available to the speaker in the language available to him at the time inspired Asafiev to form the concept of a particular 'intonational vocabulary' for a particular epoch and culture. ${ }^{9}$ Furthermore, Meillet's writings seem responsible for the fact that Asafiev's mature theory also echoed some of Durkheim's ideas. The opening paragraph of MFP presents a rather eclectic cocktail of ideas that echo Durkheim, Darwin and linguistics in general. Durkheim's indirect terminological influence appears in Asafiev's discussion on 'social consciousness" ${ }^{10}$ (sotsial'noe soznanie) and 'collective consciousness' (kollektivnoe soznanie) when determining the evolution of musical form as a process of crystallization (Asafiev [1930], 1971, $22,25)$. Asafiev used the concept in order to argue that the rules of musical production lie in social selection and must be 'socially assimilated' (usvoeny sotsial'no) (ibid., 22). In relation to memory as an essential part of musical perception, Asafiev used collective consciousness to refer to a gradual, shared experience of music in which society learns to master certain intonations as the 'most rational correlation of sound elements' (ibid.). This process forms the basic social mechanism that allows for musical communication and the evolution of all musical culture as social activity, which Asafiev presented in Intonation. Creator and listeners are presented as part of a unified cultural process of music. This communicative cultural aspect of music was later formulated into one of the features of socialist realist aesthetics, but in a very Stalinist doctrinaire form, demanding that music had to be understood by

\footnotetext{
8 About Lenin. What is our [music] department able to do? (...) c) to continue to keep up the position, which is practiced at the Institute, according to which the musical form is not a formal and indifferent schema, but a process of organic growth of musical language, and as one of the ways to form an interrelationship between people' (Asafiev [1925] in Kriukov ed. 1981, 110-111).

9 Saussure writes that although a psychologist studies the sign mechanism in the individual, it does not lead beyond individual execution and does not reach the sign, which is social (Saussure [1916], 2011, 17; Smith 2014, 116).

10 Collective consciousness was a concept broadly studied by Durkheim (ibid., 1-2).
} 
everyone. However, Asafiev's work in the 1920s was descriptive rather than prescriptive: he wanted to explain how music functioned and developed within society, not establish doctrines to be followed. Asafiev's theory was intended for anyone who wanted to hear, i.e. 'understand,' the 'working' of music beyond one's subjective taste, emotions and own time period.

The Promethean educative mission was another Silver Age theme Sovietized by Asafiev. Music was never just about sounds. It was about human hearing of tones as meaningful-in-toned-units. Asafiev differentiated between individual creativity and critical hearing, with its ability to hear new intonations of constantly changing soundscapes of culture, from socially accustomed forms of culturally hearing conventional intonations. The different types of hearing had both disintegrative and integrative effects for musical tradition and its development as a mirror of ever-changing cultural life. Musicology (through its analysis of appropriate forms of hearing) could thus actively contribute to educating the new Soviet citizen. An international nuance in Asafiev's writings also echoed Lenin's NEP policy. According to Asafiev, 'the problem of "intonational reformation" (intonatsionnaia obnovlenia), which stands in relation to deep social transformation (preobrazovania), invites those musicians that are sensitive to contemporaneity, and not only in our [country] but also in the West' (Asafiev 1925, 17).

The Promethean project of musicology continued the educational ideology of the Moscow People's Conservatory (1905-1917), especially the ideas of Boleslav Yavorsky, one of its key founding members. The new Soviet intellectual listener was also a cultural listener who was culturally civilized via national art music. Asafiev (Glebov 1927, 30-31) emphasized that classical music occupied a higher cultural level and served to elevate the lower layers of culture. With time, Asafiev believed, such lower forms of culture would completely disappear. This highlighting of the division between 'high' and 'low' forms of culture received further development in Stalinist cultural ideology when lower 'popular music' forms became identified with Western corruption, whereas higher genres of Soviet classical music were viewed as products of civilized 'culturedness' (kul'turnost) (see Dunham 1976, 22; Hoffmann 2003, 195). This leads to my fifth point.

5. Asafiev was a national and nationalist writer. Although nationalism was not politically in fashion in the 1920s, it nevertheless underpinned cultural theories. Asafiev's Orphic and Promethean musical nationalism should be connected with twentieth-century Russian messianic thought, which was based on an idea of the failure of Western modernization and lost spiritual values that had to be discovered anew. ${ }^{11}$ Asafiev followed the pre-revolutionary spiritual philosophical literature that questioned whether Russia could be the spiritual leader of modern Europe.

Asafiev developed the theoretical idea of Russian music as the spiritual leader of European classical music throughout his career. The earliest programmatic document of Asafiev's national endeavours is his plan for the journal Muzykal'naia Mysl', born out of Asafiev's defence of Stravinsky's new musical aesthetics. The national

\footnotetext{
11 The landmark study on the search for new spirituality in Asafiev's youth was the widely read publication Vekhi (1909) (Rosenthal and Bohachevsky-Chomiak eds. 1990, 22).
} 
vision of the journal Melos (1917-1918), the actual product of this plan, was based on four theses concerning religion, nationalism, tradition and European innovation: (1) music represents the creative power of culture and is, in its basic essence, a religious question; (2) the nationalist aspect of music must be developed further; (3) in searching for a 'genuine' Russianness, the value of Russian tradition is essential, but at the same time its critical re-evaluation must be stressed, especially concerning the ideas of Russian nationalism; (4) it is necessary to follow what is going on in Europe. (RGALI, f. 2658, op. 1, d. 220.) Russian writers at the time, namely Asafiev and the future Eurasianist theoretician Piotr Suvchinsky, were patriots interested in European innovations, yet they opposed both extreme uncritical Westernism and introverted Slavophileanism. However, despite these ideals, in practice Asafiev followed rather slavishly the traditional logic behind the Russian nationalist reception of European philosophical and scientific currents. The ideological platform of Melos emphasized Russian music as the purest continuation of the Ancient Greek cultural tradition, a conception also imprinted in Soviet musicology.

The cultural politics of NEP encouraged Soviet intellectuals to actively establish diplomatic relationships with foreign colleagues. This was not only advantageous with respect to Asafiev's and Suvchinsky's 'fourth thesis', which Asafiev realized in his aesthetic programme for the Leningrad branch of the Association of Contemporary Music $\left(\mathrm{ASM}^{12}\right.$ ), but also the more conventional continuation of the Slavophilean nationalist project. In A book about Stravinsky (1929), Asafiev connected Stravinsky's music with ancient Russian folk traditions while consciously painting a portrait of his music as a universally humane, yet particularly Russian, musical outlook on modernity. Soviet cultural policy of the 1920s influenced Asafiev's national new music project as an ASM critic between 1924 and 1928: a Bergson-influenced criticism of intellectualism increasingly came under the influence of Max Weber's (1921) analysis of European rationalism. Overall, Asafiev's Russian modernist music apology is a reception history of Paul Bekker's analytical new music criticism in the early Soviet ideological context. ${ }^{13}$ Speaking out against the rationalist tendencies of Western culture in a nationalist and Weberian theoretical spirit, Asafiev comes up with dual definitions of European musical rationalism in an article written for ASM's journal Sovremennaia muzyka in 1926: as harmful in an academic context and non-harmful in an intellectual one (Glebov [1926], 1975, 269). The latter notion, represented by Arnold Schoenberg for example, was applicable in Russia.

We find a similar logic in Asafiev's definition of the term 'songfulness' (pesennost'). The theoretical origins of the socialist realist understanding of songfulness lie partly in Asafiev's nationalist reception of Ernst Kurth's theory of linear counterpoint (Grundlagen des linearen Kontrapunkts, 1917), which he juxtaposed to Hugo Riemann's harmonic analysis of music. Asafiev applied Kurth most famously in $M F P$, but also in his cultural criticism of Western composers, combining it with Weber's sociological treatise 'The Rational and Social Foundations of Music'

\footnotetext{
12 Assotsiatsiia Sovremennaia Muzyka.

13 Even if not immune to nationalist rhetoric, Bekker had stood for the concept of an internationalist, critical and innovative new music since the First World War (Heile 2009, 7).
} 
(1921). By songfulness, Asafiev was referring to the dominant quality of linearity and melodic aspect in music. According to Weber, melody had become subordinated to the harmonic principle in Western music. Weber wrote that polyphony, which had almost everywhere emerged in the area of folk music, had developed into harmonic music in Western musical culture. In this way, polyphony had become rationalized in the Western context and was dominated by technical principles (Bruun and Whimster 2012, 323). In Weber's analysis, this was not exactly a value-oriented so much as an empirical point. However, Asafiev emphasized emotional quality, linearity and polyphony as the dominating characteristic of Russian art music, juxtaposing them to Western rationality, and he argued that linearity and 'polyphonic thinking' (polifonicheskoe myslenie) were linked with moral and ethical values (Glebov [1926], 1982, 178). Asafiev's Stravinsky was a Russian composer capable of fulfilling a universal mission that both Wagner and Scriabin had failed to do: providing an alternative path for over-rationalized, Western European culture.

6. Asafiev was a henchman of Stalinism, but not a Stalinist henchman. How should we conceive of the relationship between Asafiev and the politically-based Stalinist socialist realist discourse of music? Asafiev had a double-edged relationship not only with Stalinist politics, but, as we have witnessed, also with Russian politics in general. Thus, my thesis addresses the conventional question of whether Asafiev was a victim of Stalin's Great Break or a functionary in the Stalinist antiformalist campaigns of the 1940s. The answer to both parts of the question is yes: Asafiev was neither a passive victim nor a straightforward architect of Stalinist political campaigns in the sphere of art. This point can be stated about other intellectuals as well, and it forms the starting point for my current revisionist research project on the intellectual history of Stalin-era musicology.

The process of Sovietization remained a two-edged sword throughout Asafiev's career. The more he schemed and attempted to accommodate his cultural vision politically, the more he became entangled with destructive practices, leading to a rather nationalist and value-hierarchical interpretation of his theory of music during the Stalin-era. ${ }^{14}$ In the same breath, it must be noted that Asafiev's intonation theory bears theoretical values when placed in the intellectual history of semiotics and musicology in general. Curiously, the theory is particularly interesting from the standpoint of popular music analysis. As Monelle $(1992,279)$ notes, none of Asafiev's analytical concepts are inherently limited to Western music, although he borrowed his examples from this sphere. For example, Asafiev's metaphoric idea that song is a concentration of human vitality has theoretical value, as Zak (1982, 91-111) highlights in his analysis of popular song and Asafiev's idea of the re-intoning process. Regarding the Stalinist political context in general and revisionist contemporary analysis of the concept of Stalinism (as a culture of politics) and culture in particular, we should underline these values, along with the fact that Intonation is not any type of Stalinist exposition of music, although Asafiev simultaneously produced articles for Stalinist cultural political use. Therefore, the interesting questions

\footnotetext{
14 Frolova-Walker and Walker (2012) makes a similar point more generally about music and intelligentsia.
} 
for further study are as follows: What did this double-edged relationship of a 'Soviet bourgeois' musical revolutionary with Stalinist aesthetic discourse produce in the 1930s and 1940s? Does Intonation reflect a Stalinist context, and if so, in what way? What are the ultimate results of Asafiev's musical revolutionarism? In the continuum of Soviet cultural revolution in general, and Soviet intellectual revolution in particular, Stalin's 'Great Break' with Soviet bourgeois' traditions can be seen as just another political campaign. The Great Break was hardly able to remove the intellectual traditions it attacked, nor seemingly was this its ultimate aim. Instead, it viciously channelled the established Soviet intellectual traditions of the 1920s. Let us thus take a quick look at the Stalinist context wherein Asafiev finished his theoretical monographs and briefly discuss some of the continuums that take place among the 'breaks' encouraged by Stalinism.

A clear generational and conceptual shift began in the late 1920s due to an abrupt policy change in Communist Party politics. Intellectuals like Asafiev, who were cut off from political support during the Great Break, were largely non-communists or non-Party members who had to that point possessed cultural political power in their particular professional or artistic fields. Asafiev did not withdraw from his musicological career without trying to prove that his theory and activity were ideologically correct and designed to serve the needs of the state. ${ }^{15}$ He was also ready to develop his theory further according to Marxist-Leninist principles (Asafiev in Koreva 1930, 242-244). In fact, Asafiev turned to the Soviet Marxist philosopher Abram Deborin in 1929, when he sought new Soviet Marxist philosophical sources to apply dialectical-materialism to his theory (Orlova and Kriukov 1984, 188).

No apologies helped within the context of the Great Break. The criticism by the Russian Association of Proletarian Musicians (RAPM) ${ }^{16}$ of the former members of its rival association, ASM, lacked substance, as it merely followed Agitprop's criticism of the Soviet cultural bourgeois-the non-Party intelligentsia in general-and was part of a power play by the association in particular (see Proletarskii Muzykant 1929, No. 2, 28, 31; David-Fox 2015, 125). In this context, Asafiev began a serious career as a composer and became recognized as a major Soviet ballet composer in the 1930s. ${ }^{17}$ Curiously, there are no crucial contradictions between Asafiev's writings in the 1920s and his compositions of the 1930s (as has been sometimes claimed). Quite the contrary, the articles Asafiev wrote about his own musical process, selection of materials, and so forth, shows a logical continuum of his theoretical perceptions (see, e.g. Asafiev [1934], 1957, 138-140). The contradiction, or break with traditions, lies not between his writings and his compositions, or between his writings and socialist realist principles, but between his compositions and the modernist compositions that had nourished his theoretical writings. As much as Asafiev's theory was inspired by the modernist music of the 1920s, his own rather conventional compositions appear as the practical realizations of his theory in the far from monolithic patriotic political

\footnotetext{
15 Asafiev's letters to Lunachrski between 1929 and 1931 indicate this clearly (Viljanen 2016, 606-614).

16 Rossiiskaia assotsiatsiia proletarskikh muzykantov.

17 The list of Asafiev's output contains 202 compositions. He wrote twenty-eight ballets.
} 
context of the Stalin-era. This caused great confusion at the time, since Asafiev's colleagues had expected him to use modern compositional language to deliver his musicological ideas. His former student, theater critic Ivan Sollertinski, an admirer of Shostakovich, noted that, regarding Asafiev's ballet The Flames of Paris, what was promised on paper was not realized all that well in Asafiev's artistic practice (Sollertinski [1932], in Miheeva ed. 1978, 98).

Meanwhile, Asafiev's theoretical concepts developed a life of their own in the socialist realist criticism and scholarship developed by his students, such as Mikhail Druskin, Roman Gruber and Sollertinsky. Furthermore, the active Party member Viktor Gorodinski is a good example of a musicologist who tried to lay down a theoretical basis for socialist realist discourse on music in the pages of Sovetskaia muzyka using Asafiev's theory (Gorodinski 1933, 6-18). The 'break' with the traditions of the 1920s arose mostly in how the actual intellectual origins of Asafiev's theory were obscured. Asafiev contributed by participating in the ritual of self-criticism. In his autobiographical article 'Moi Put', which was published at the time that socialist realism first appeared on the scene, Asafiev explains self-critically that he had found dialectical and historical materialism after a long 'romantic utopian journey' (Asafiev 1934, 48).

Asafiev's second writing period began around the time when an article on Asafiev-Glebov as a critic appeared in Sovetskaia muzyka in 1940. In the article, Daniel Zhitomirski (1940, 5-14) compares Asafiev to Tolstoy, Stasov and Stanislavski. A new generation of Muscovite musicologists urged Asafiev to return to writing just before the war. The radical hermeneutical shifts in Stalinist ideology in the second half of the 1930s and before the Second World War greatly shaped Asafiev's style of writing. At the beginning of his second writing period, he doubted his abilities to express his thoughts from the new perspective asked by Soviet censorship (see Kabalevski 1974, 303). However, the patriotic atmosphere of the Great Patriotic War changed everything. Patriotism inspired him to adopt the 'simpler' voice of Tolstoy as he stepped back into the role of the foremost theoretical authority on Soviet music. In his grand writing plan 'Ideas and thoughts' (Mysli i dumy, 1941), Asafiev notes how old age and illness had prevented him from developing 'all the previously worked ideas into grand works ....' 'However,' he adds, 'I would like to rescue them as they might be useful. ... I will attempt to give up now the remainder of my days [to such an endeavour].' According to Asafiev, 'Ideas and thoughts' presented 'a maximal and laconic record of [his] past experiences and thoughts, like a summary' (Asafiev [1941] in Kabalevski ed. 1957, 331). The second writing period was thus not as much a new creative period as it was a period of rewriting, sometimes also reinterpreting his previous work.

He completed Intonation on 24 January 1942. In comparison with MFP, its language is simpler. The text does not include any direct quotes or precise references to existing literature because Asafiev could not use his library during the war. His large-scale works written during the war were published posthumously. It seems that various strokes invalidicized him, preventing from refining his manuscripts.

Already in the introduction, Intonation demonstrates Asafiev's double-edged relationship with Stalin era political discourse regarding music. First, Asafiev 
claimed that he was pleased by the institutionalization of his term 'symphonism' (simfonizm):

Not so long ago I introduced and validated in musicology the term simfonizm along with several others. With a feeling of satisfaction, I see that simfonizm and the conceptual terms, which I introduced, have become established and are helpful in generalizing and explaining some musical phenomena, formerly bypassed with no attention at all, or with very little being directed toward them, because of the disassociation of facts which were, in fact, similar or jointed by common sources. Perhaps such an essential concept as intonation will have the luck also to come into more general usage. (Asafiev [1947], [Tull trans.] 1977, 606)

Further on, he noted that he was not happy with how his theoretical concept 'musical semantics' (muzykal'naia semantika) had been applied in practice. It was a linguistic term introduced in MFP (Asafiev [1930] 1971, 208) replacing musical symbolism as an outdated term of 'formal aesthetics':

I have renounced my term 'musical semantics', which has become established, but, alas not in the same sense as I conceived it (cf. MFP). The pre-eminence of content in music has always existed for me. But I am accustomed to hear that content in a musical composition which has been organized by the composer, and not 'to listen to a symphony' under an idea, pre-determined for it from outside - an idea which is philosophically valuable, perhaps, but which is not in the given composition of the given composer, and never could be. (Asafiev [1947], [Tull trans.] 1977, 608)

Asafiev's renouncement of musical semantics is significant in the Stalinist context, since as Monelle $(1992,278)$ points out, Intonation theory is a radical semantic theory in the sense that it talks about music as an art of intoned meaning. This nevertheless does not constitute a contradiction if we understand the way Asafiev conceived of and developed classic musical formalism in his output. Furthermore, in a Stalinist context his foremost purpose seems to have been to emphasize to Soviet readers that music has no denotative and literary meaning (see also ibid.). Thus, as Taruskin (2010, 799-780) suggests, Asafiev's theory is firmly rooted in a classic formalist attitude-for him, musical content literally means autonomous musical content, while the rules of musical formation are determined by social conditions. The concept of intonation functions as a bridge between music and social reality. Thus, contrary to Taruskin's further suggestion, Asafiev's theory denies rather than confirms the possibility of ideinost' in music in its socialist realist literary meaning of 'ideological content', and thus there is no irony in this sense. Rather, it explains why he loudly abandoned semantics in his second theoretical monograph. Instead, he concentrated on reflecting on how we should conceive of 'realism' (realizm) 
and 'narodnost,' 18 and why 'typicality' (tipichnost') and 'generalization' (obobshchenie) are such effective methods in music as a historical and social phenomenon of intonation:

'When I state that the roots of realistic in music lie in the intonational communication of people, and in the recognition of these socializing elements of music in the compositions of the musical past and present, I am trying to base the problem of musical realism on the unquestionability of the experience of musical communication, on the continuously occurring process of assimilation, evaluation, recognition and non-recognition of music of one's environment.' (Asafiev [1947], [Tull trans.] 1977, 729)

In Intonation, Asafiev criticized the Soviet political understanding of formalism for designating a work of art, which had no content beyond an aesthetic one or else a content that was seen as anti-Soviet or anti-socialist. Instead, according to Asafiev, musical work was often conceived as 'formal' because it was 'inaudible,' i.e. not heard as meaningful by the audience. However, he clarified, 'this is not because [such works] are unconditionally "decadent," but because [the composer's] "personal expression" is not audible' (Asafiev [1947], [Tull trans.] 1977, 941). This means that the progress of music as intonational art does not consist only of the invention of subjective and unusual tonal materials by an individual (ibid., 940). Instead, when 'passing through the mind, the intellectual culture and the ideational purposefulness of the thinking composer, the most popular intonations of the epoch become a living source of music of a high intellectual level' (ibid.). Intonation provides a laconic sociological and intellectual historical analysis of the way in which the ideals of Soviet musical culture functioned in practice: the real 'authentic history of music... as the voice of reality and as ideationally cognitive activity,' have been created by 'listeners, the masses, everyone to whom music is dear', Asafiev writes (ibid., 945-946). However, he also talks about the 'ruthless' down sides of the public deciding on just what constitutes the most socially viable form of music. According to him, 'it overtakes the genius, the intellectualistic prospector of new paths, and the modest singer of lyrical sentiments equally' (ibid., 941).

Approximately half a decade of 'high Stalinist' music politics separates the point at which Asafiev finished Intonation and when it was published. From the standpoint of a far from clear question regarding what the relationship of music and politics might mean on different levels and from different perspectives, I find it interesting that when Asafiev died in 1949, his words and ideas represented the complete 'anti-thesis' of what his artistic and scholarly work had originally stood for. Such articles as 'Music for Millions' (1947) testifies to the insane extremist interpretation that Asafiev allowed for his intonation theory in the Stalinist context. Furthermore, Asafiev's 1948 speech 'For New Aesthetics, for Socialist Realism' as the head of the Composer's Union not only condemned the composers he had admired throughout his active career as a critic, the speech was also pure self-criticism that denounced the philosophical origins of his music theory-he turned against himself:

\footnotetext{
18 Asafiev's definition of narodnost' in music is based mostly on a selection of 'folk intonations' as the basis of an artistic composition and on a musicological conception of narodnaia muzyka (folk music) as the oral tradition of music.
} 
In the current bourgeois society, philosophy and aesthetics are infiltrated by shady pessimism. This ideology of a dead-end society evokes doctrinization and philosophical cosseting from [Nikolai] Hartmann [1882-1950] to Oswald Shpengler [1880-1936], from Bergson to Nietzsche, finding peace in the twilight of the Freudian theory about subconscious, in the irrational mysticism of [Emmanuel] Swedenborg [1688-1772]. In that kind of society, the spirit of creation is naturally submitted to a spiritual diaspora. (Asafiev 1948, 17)

What can we conclude? What intervened in his thinking between writing (1942) and publishing (1947) Intonation? After the war, Asafiev's relationship with politics changed. We no longer encounter a critic and music philosopher who determined and designed the politics of music (aesthetics) and the relationship between aesthetics and Soviet society and politics, which had been Asafiev's mission in the 1920s when forming his grand theory. We encounter a theoretician-a henchman of Stalinism-who gives the authorship of his 'cultural theory of music' to Stalin's governmental officer, namely Zhdanov. I disagree with Zuk's (2019) interpretation of Asafiev as a willing participant in Stalinist politics, i.e. a Stalinist henchman, although no doubt he had his reasons for participating in such politics. More than anything, the year 1948 in music-with all its displays of extremist accusations, false testimonies and apologies-testifies, among other things, to the success of Stalinist politics in turning people against each other and diminishing their autonomy. On the other hand, it is curious that Intonation was published amidst the anti-formalist campaigns. Whereas Zuk (2019) and Herrala (2012, 287-318) point out that Asafiev's collectively written 1948 speech used direct lines from his articles from the 1920s, while surrendering to Zhdanovshchian principles, none of this takes place in Intonation. There are no Marx-quotes or Stalin-references, even if I have argued here that MarxistLeninist discourse in its broadest sense influenced Asafiev's theoretical thinking. On a philosophical level, Intonation builds logically upon Asafiev's Russian cultural mission of music that is true to his original Silver Age quest. The most crucial difference is that there are no individual 'Orphic' heroes. Instead, Asafiev grants music itself the Orphic social mission. His penetrating historical idea seeks to demonstrate that music has been developing for centuries towards an independent medium of expression, which serves as a direct manifestation not just of human culture and society; instead, the creator and the listeners appear as part of a 'unified' cultural process of music. Intonation ambitiously presents European intellectual history through a linguistic and sociological analysis of music. Asafiev's views of music history are not Hegelian or evolutionary in nature. His theory is cyclical and organic in modernist philosophical fashion.

To conclude, whereas Asafiev's 1948 speech draws a picture of a Stalinist, totalitarian culture, the publication of Intonation amidst the anti-formalist campaigns speaks against such an idea and instead shows how ultimately intellectual culture managed to manifest itself one way or another in the Stalinist context. Still in the 1942, Asafiev managed to develop manifold philosophical and scientific precepts into a concise theoretical form. Participating in the Stalinist discourse as the head 
of Soviet music in 1948, he secured, among other things, that Intonation, his final legacy for Soviet musical culture, would survive.

\section{Conclusions}

Classical music gained a high cultural position during the early Soviet period, which it maintained right up to the collapse of the Soviet Union. This high cultural position was far from predetermined: for many early revolutionaries, it was a relic of the elitist traditions of bourgeois culture. In this context, Asafiev emerged as one of the most important early defenders of Russian intellectual traditions of music that emphasize its autonomous social value. I have shown that Asafiev was never an apolitical writer, as Taruskin (2010) suggests when referring to Asafiev's early musicological and critical output. He not only participated in the recycling of nationalist myths and the creation of early Soviet cultural nationalism, he also applied in his theory such officially promoted grand scientific trends of the 1920s as sociology and linguistics in order to make his theory useful for Leninist cultural politics. Despite intellectual disputes over the content and shape the new culture and art should take, cultural theoreticians under the flag of Leninism sought creative answers, not only for the direction and philosophy of the new culture and arts, but also to the question of the legacy of great works of art and what intellectuals should gradually be adopted as the accepted forerunners and role models of Marxist-Leninist_and therefore also Soviet humanistic_discourse.

The Asafiev case provides one key to understanding the process that many fields and representatives of Russian intellectual culture went through to become recognized cultural workers and symbols of the new Soviet society. The literary legacy of such cultural theoreticians helps to explain not only Soviet culture after the Stalin era, but also how Bolshevik ideology was gradually merged with preRevolutionary traditions.

This article demonstrates that the Soviet political context is too narrow a hermeneutical framework for understanding the ideas that materialized in cultural policy during periods of political change. Instead, Asafiev's literary output is a piece of not just Russian history, but also of our shared European intellectual history. The close analysis of the theoretical development of Soviet musicology in the broader European context challenges the conventional historical narrative of Soviet particularity after the October Revolution from the standpoint of Russian and European intellectual traditions. The ideas that Asafiev's cultural theory of music presents are by no means unique to the Soviet context. Quite the contrary: they both echo values and Russian cultural identity of the tsarist period and owe a great deal to general European intellectual history.

I have also shown the complex process through which Silver Age ideas reverberated in Asafiev's cultural theory of music during the Soviet period. Though claiming to be a break from the tsarist cultural philosophical tradition, the Soviet cultural revolution was based on the continuation of various core ideas. The new Soviet context allowed Asafiev to package his Silver Age vision into a politically applicable theoretical form. A good example of this is Asafiev's 
pre-Revolutionary search for philosophical and social unity through music. The turbulent context of numerous wars - the First World War (Russia's Great War), a civil war, a 'class war' (Stalin's Great Break), a 'war against state enemies' (Stalin's terror) and the Second World War (the Great Patriotic War)-explains to some extent why the idea of restoring a 'lost' unity of Russian society through music remained so powerful throughout Asafiev's career. Furthermore, the allunifying aspect of his theory of intonation explains why it is so easy to connect Asafiev's 1920s output with the all-unifying doctrine of socialist realism, the Stalinist tool to bring together a society fragmented by 'class war' politics. However, rather than linking Asafiev's theory and Stalinist socialist realist doctrine, we should explore how they coexisted and what their coexistence created.

Acknowledgements Open access funding provided by University of Helsinki including Helsinki University Central Hospital.

Funding This study was funded by the Ella and Georg Ehrnrooth Foundation and Univeristy of Helsinki, the Faculty of Arts: Aleksanteri Institute.

\section{Compliance with ethical standards}

Conflict of interest The author declares that she has no conflict of interest.

Open Access This article is licensed under a Creative Commons Attribution 4.0 International License, which permits use, sharing, adaptation, distribution and reproduction in any medium or format, as long as you give appropriate credit to the original author(s) and the source, provide a link to the Creative Commons licence, and indicate if changes were made. The images or other third party material in this article are included in the article's Creative Commons licence, unless indicated otherwise in a credit line to the material. If material is not included in the article's Creative Commons licence and your intended use is not permitted by statutory regulation or exceeds the permitted use, you will need to obtain permission directly from the copyright holder. To view a copy of this licence, visit http://creativecommons.org/licen ses/by/4.0/.

\section{References}

RGALI, f. 2658, op. 1, d. 220. Asafiev, Boris 1917. B. V. Asafiev, V. V. Gippius i P. P. Suvchinskii. Prospekt izdaniia zhurnala. 28.4.1917.

Proletarskii Muzykant 1929, Nos. 2, 28, 31.

Asafiev, B. (1925). Sovremennoe Russkoe muzykoznanie i ego istoricheskie zadachi. In De Muzyka. No. 1 (pp. 5-27). Leningrad.

Asafiev, B. ([1930, 1947], 1971). Muzykal'naia forma kak protsess (and Intonatsiia) Leningradskoe otdelenie: Muzyka.

Asafiev, B. ([1934], 1957). Muzyka “Tret'ego sosloviia.” In Akademik B. V. Asaf'ev. Izbrannye Trudy Vol. V. (pp. 138-140). Moscow: Izdatel'stvo Akademii Nauk SSSR.

Asafiev, B. (1934). Moi Put'. Sovetskaia Muzyka, No. 8. (p. 48). Moscow.

Asafiev, B. ([1941], 1974). O sebe. In A. Kryukov (Ed.) Vospominaniia o B. V. Asaf'eve (pp. 317-508). Leningrad: Muzyka.

Asafiev, B. (1948). Za novuiu muzyka'nuiu estetiku, za sotsialistichekii realism! In Sovetskaya Muzyka 1948:2, (pp. 12-22).

Asafiev, B. (\& Orlova, E. ed.), ([1930, 1947], 1971). Muzykal'naia forma kak protsess. Leningrad: Muzgiz. 
Asafiev, B. (\& Tull, J. ed. \& trans.) 1977. B. V. Asafjev's Musical Form as a Process. Translation and Commentary. Dissertation. The Ohio State University. Microfilm-xerography. Ann Arbor, Michigan, U.S.A., London, England: University Microfilms International, 1979.

Bartlett, R. (1995). Wagner and Russia. Cambridge: Cambridge University Press.

Bartlett, R. (2011). Tolstoy: A Russian life. New York: Houghton Mifflin Harcourt Publishing Company.

Bruun, H. \& Whimster, S. eds. \& trans. (2012). The meaning of "value freedom" in the sociological and economic sciences. In Max Weber: Collected methodological writings (pp. 304-335). New York: Routledge.

Bussanich, J. (1996). Plotinus's metaphysics of the One. In L. Gerson (Ed.), The Cambridge Companion to Plotinus (pp. 38-66). Cambridge: Cambridge University Press.

Clark, K. (1996). Petersburg. Crucible of cultural revolution. Cambridge, MA: Harvard University Press.

Cook, N. (2013). Beyond the score: Music as performance. Oxford: Oxford University Press.

David-Fox, M. (2015). Crossing borders: Modernity, ideology, and culture in Russia and the Soviet Union. Pittsburgh: University of Pittsburgh Press.

Dunham, V. (1976). In Stalin's time: Middleclass values in Soviet Fiction. New York: Duke University Press.

Frolova-Walker, M., \& Walker, J. (2012). Music and power 1917-1932. Woodbridge: The Boydell Press.

Gasparov, B., Hudghes, R., \& Paperno, I. (Eds.). (1992). Cultural mythologies of Russian modernism from golden age to the silver age. Berkeley: University of California Press.

Glebov, I. ([1915], 1980). Ot opytov k novym dostizheniam. In A. B. Pvalova-Abenina \& B. A. Kats (Eds.) $O$ khorovom iskusstve. (pp. 96-100). Leningrad: Muzyka.

Glebov, I. ([1916], 2006). Samoe sovremennoe sochinenie. Po povodu Requiem'a A. D. Kastal'skogo. In S. Zvereva (Ed.) Russkaia dukhovnaia muzyka $v$ dokumentakh i materialakh. Vol. 5. Aleksandr Kastal'skii. Stat'i, materialy, vospominaniia, perepiska (pp. 266-277). Moscow: Znak.

Glebov, I. (1917). Soblazny preodoleniia. In I. Glebov \& P. Suvchinski (Eds.), Melos: Knigi o musike (Vol. 1, pp. 3-27). Saint Petersburg: Petrograd.

Glebov, I. (1918). Puti v budushee. In I. Glebov \& P. Suvchinski (Eds.), Melos: Knigi o muzyke (Vol. 2, pp. 50-96). Saint Petersburg: Petrograd.

Glebov, I. ([1918], 2003). Pathways into the future. In S. Campbell (Ed. \& trans.), Russians on Russian music, 1880-1917. An Anthology (pp. 234-258). Cambridge, UK: Cambridge University Press.

Glebov, I., (1921). Russkaia poeziia v russkoi muzyke. Muzykal'nyi otdel N. K. P. Peterburg: Gosudarstvennoe izdatel'stvo.

Glebov, I., (1922a). Stikhotvoreniia v sovremennoi Russkoi Muzyke. In Orfei. Knigi o muzyke, Vol. 1. (pp. 80-101). Petrograd.

Glebov, I., (1922b). U istokov zhizni. Pamiati Pushkina. In Orfei. Knigi o muzyke, Vol. 1. (pp. 7-34) Petrograd.

Glebov, I., (1923a). Tsennost Muzyki. In I. Glebov (Ed.) De Musica (pp. 5-34). Petrogradskaia Gosudartvennaia Akademicheskaia Filarmoniia.

Glebov, I. (1923b.) Protsess oformleniia zvuchashchego veshchestva. In. I. Glebov (Ed.) De Musica (pp. 144 - 146). Petrogradskaia Gosudartvennaia Akademicheskaia Filarmoniia.

Glebov, I. ([1926], 1975). Kshenek i Berg kak opernye kompozitory. In L. A. Pavlova-Arbenina (Ed.) $B$. Asaf'ev. Ob Opere (pp. 308-316). Leningrad: Muzyka.

Glebov, I. ([1926], 1982). O polifonicheskom iskusstve, ob organnoi kul'ture i o muzykal'noi sovremennosti. In A. N. Dimitriev (Ed.) B. Asaf'ev o muzyke XX veka. Leningrad: Muzyka.

Glebov, I. (1927). Bytovaia muzyka posle oktiabria. In Novaia Muzyka vyp. 1 (V) (pp. 17-32). Leningrad.

Gorodinski, V. (1933). K voprosu o sotsialisticheskom realizme v muzyke. In Sovetskaia muzyka No.1. (pp. 6-18).

Groenberg, K. (1997). 'The Shade of Lucifer's Dark Wing.' Satanism in Silver Age Russia. In B. Rosenthal (Ed.), The Occult in Russian and Soviet Culture (pp. 99-134). Ithaca: The Cornell University Press.

Gustafson, R., \& Kornblatt, J. (Eds.). (1996). Russian religious thought. Madison: University of Wisconsin Press.

Heile, B. (2009). The modernist legacy: Essays on new music. Farnham: Ashgate.

Herrala, M. (2012). The struggle for control of Soviet music from 1932 to 1948. Socialist realism vs. Western formalism. Lewinston: Edwin Mellen Press.

Hoffmann, D. (2003). Stalinist values: The cultural norms of soviet modernity, 1917-1941. Ithaca, London: Cornell University Press.

Kabalevski, D. (1974). Vosem' pisem B. V. Asaf'eva. In A. Kriukov (Ed.), Vospominaniia o B. V. Asaf'eve (pp. 298-316). Leningrad: Muzyka. 
Kabalevski, D. ed. (1952-1957). Akademik B. V. Asafiev Izbrannye Trudy. Vol. I-V. Izdatel'stvo akademii nauk SSSR.

Karnes, K. (2008). Music criticism and the challenge of history. Oxford: Oxford University Press.

Kriukov, A. (Ed.). (1974). Vospominaniia o B. V. Asaf'eve. Leningrad: Muzyka.

Kriukov, A. (Ed.). (1981). Materialy k biografii B. Asafieva. Leningrad: Muzyka.

Koreva, S. (Ed.). (1930). Nash Muzykal'nyi front. Materialy vserossiiskoi muzykal'noi konferentsii (Iun', $1929 \mathrm{~g}$ ). Moscow: Gosudarstvennoe Izdatel'stvo Muzykalnyi sektor.

Larosh, H. ([1885], 2003). A new opera from the Young Russian School. In Campbell S. (Ed. \& trans.), Russians on Russian music, 1880-1917. An Anthology (pp. 42-53). Cambridge, UK: Cambridge University Press.

Leikin, A. (2011). The performing style of Aleksandr Scriabin. Farnham: Ashgate.

Leroux, G. (1996). Human freedom in the Thought of Plotinus. In L. Gerson (Ed.), The Cambridge Companion to Plotinus (pp. 292-314). Cambridge: Cambridge University Press.

Losski, N. (1917). Zvuk, kak osoboe tsarstvo bytiia. In I. Glebov \& P. Suvchinski (Eds.), Melos. Knigi o Muzyke (Vol. 1, pp. 28-34). Saint Petersburg: Petrograd.

Losski, N. ([1915], 1991). Mir kak organicheskoe tseloe. In Izbrannoe. Prilozhenie k zhurnalu Vorprosy filosofii (pp. 338-483). Moscow: Izdatel'stvo "Pravda.

Miheeva, L. ed. (1978). Pamiati I. I. Sollertinskogo. Vospominania, materialy, issledovaniia. Leningrad: Sovertskii kompozitor.

Mitchell, R. (2016). Nietzsche's orphans: Music, metaphysic, and the twilight of the Russian empire. New Haven: Yale University Press.

Monelle, R. (1992). Linguistics and semiotics in music. London: Routledge.

Mullarkey, J. (2009). Henri Bergson. In G. Oppy \& N. Trakakis (Eds.), Twentieth-century philosophy of religion. Oxon: Routledge.

Orlova, E. (Ed.). (1965). B. Asafiev. Rechevaia intonatsiia. Moscow: Izdatel'stvo Muzyka.

Orlova, E. (1970). "Simfonicheskie etiudy" v puti Asaf' eva issledovatelia russkoi muzyki. In B. Asafiev (Ed.), Simfonichekie Etiudy (pp. 3-14). Leningrad: Muzyka.

Orlova, E. (1982). Nauchnaia problematika rannykh rabot Asafieva v svete zadach sovremennogo muzykozaniia. In Problemy traditsii i novatorstva v soremennoi muzyke, (pp. 205-231). Moscow.

Orlova, E., \& Kriukov, A. (1984). Akademik Boris Vladimirovich Asaf'ev Monografiia. Leningrad: Sovetskii Kompozitor.

Orlova, E. (1984). Intonatsionnaia teoriia Asaf'eva kak uchenie o spetsifike muzykal'nogo myshleniia. Moscow: Muzyke.

Osborne, Nigel. (1986). La Forme musicale comme processus. Inernational Review of the Aesthetics and Sociology of Music, 17(2), 215-222.

Panteeleva, O. (2015). Formation of Russian Musicology from Sacchetti to Asafyev, 1885-1931. Dissertation (Doctor of Philosophy). University of California, Berkley.

Rosenthal, B., \& Bohachevsky-Chomiak, M. (Eds.). (1990). A revolution of the spirit: Crisis of value in Russia, 1890-1924. New York: Fordham University Press.

Saussure, F. de ([1916], 2011). Course in General Linguistics. New York: Columbia University Press.

Sepman I. (2003). Vospominaii tselyi tom... In I. V. Selman (Ed.), Rossiiskii Institut Istorii Iskusstv v Memuarakh (pp. 5-8). St. Petersburg: RIII.

Smith, K. (2014). Émile Durkheim and the Collective Consciousness of Society. A study in Criminology. New York: Anthem Press.

Stites, R. (2005). Serfdom, society, and the arts in imperial Russia. The pleasure and the power. New Haven: Yale University Press.

Stasov, V. (1962). Stasov V. V. Pismo k rodnym (Vol. 3). Moscow: Gosudarstvennaia muzykal'naia izdatel'stva.

Tarasti, E. (2002). Signs of music: A guide to musical semiotics. Berlin: Mouton de Gruyter.

Taruskin, R. (2010). The Oxford Dictionary of Western Music (Vol. IV). Oxford: Oxford University Press.

Tompakova, O. (1997). Skriabin v khudoxhestvennom mire Moskvu kontsa XIX-nachala XX veka. Moscow: Muzyka.

Valkova, V. (1999). Ot 'Otchestvlennoi romantiki' k sotsial'nomu zakazu: Asafiev - kritik na perelome epokh (1914-1924 gody). In Iskusstvo XX veka: dialog epokh i pokolenii Vol. 2. (pp.17-29). Nizhnyi Novgorod: Nizhegorodskaia gos. konservatoriia im. M.I. Glinki.

Weber, M. ([1921], 1958). The Rational and Social Foundations of Music. D. Martindale, J. Riedel and G. Neuwirth (Eds. \& trans.). London and Amsterdam: Southern Illinois University Press. 
Viljanen, E. (2016). The problem of the modern and tradition: Early Soviet musical culture and the musicological theory of Boris Asafiev (1884-1949). Acta Semiotica Fennica L, Approaches to Musical Semiotics 23 .

Voloshinov, V. ([1929], 1986). Marxism and the philosophy of language. Translated by L. Matejka and I. Tiunik. Boston: Harvard University Press.

Zak, V. (1982). Asaf'ev's theory of intonation and the analysis of popular song. In R. Middleton \& D. Horn (Eds.), Popular music 2. Theory and method (pp. 91-110). Cambridge: Cambridge University Press.

Zuk, P. (2019). Boris Asafiev in 1948. Journal of the Royal Musical Association, 144(1), 123-156. https:// doi.org/10.1080/02690403.2019.1575591.

Zhitomirski, D. (1940). Igor Glebov kak publitsist. Sovetskaia Muzyka, No. 12, (pp. 5-14). Moscow.

Publisher's Note Springer Nature remains neutral with regard to jurisdictional claims in published maps and institutional affiliations. 